\title{
PENGGUNAAN ALAT PELINDUNG DIRI (APD) DALAM UPAYA \\ PENCEGAHAN PENYAKIT AKIBAT KERJA
}

\author{
Inayah Husna Sibarani / inayahhusna08@gmail.com
}

\section{LATAR BELAKANG}

Rumah Sakit merupakan tempat kerja serta tempat berkumpulnya orangorang sehat (petugas dan pengunjung) dan orang- orang sakit (pasien) sehingga rumah sakit merupakan tempat kerja yang mempunyai risiko tinggi terhadap penyakit akibat kerja maupun penyakit akibat kecelakaan kerja. Resiko kontak dengan agen penyakit menular, dengan darah dan cairan tubuh maupun tertusuk jarum, instrumen tajam yang dapat berperan sebagai tranmisi berbagai penyakit, seperti hepatitis B, HIV/AIDS, perawat merupakan petugas kesehatan terbanyak dengan komposisi hampir $60 \%$ dari seluruh petugas kesehatan di rumah sakit dan salah satu profesi yang sering terkena penyakit akibat kerja karena perawat tenaga kesehatan yang 24 jam berada di samping dan bersentuhan dengan pasien, terlebih perawat bedah yang bekerja di kamar operasi yang banyak melakukan tindakan dengan memakai instrumen tajam, suasana kerja dengan tekanan stres yang tinggi, kelelahan yang berpotensi menyebabkan kecelakaan kerja.
Penularan infeksi yang terjadi pada perawat bedah dapat disebabkan oleh tindakan keperawatan yang dilakukan sering kontak dengan darah, jaringan, dan sekresi cairan yang yang masuk kedalam tubuh baik karena tertusuk jarum atau luka, mukosa yang kepercikan oleh darah, cairan yang mengandung kuman dari pasien berpotensi menimbulkan infeksi. Salah satu penyebabnya karena mereka bekerja tidak pakai alat pelindung diri (APD) sarung tangan, mereka tidak patuh menggunakan APD.

Perilaku kesehatan dan keselamatan kerja perawat di rumah sakit sangat penting, karena tindakan perawat sekecil apapun dapat menimbulkan risiko terhadap perawat dan pasien. Banyak penelitian yang menunjukan rendahnya kepatuhan terhadap penggunaan APD. Data hasil penelitian Aarabi et.al (2008) menyatakan hanya $33,9 \%$ dari 250 tenaga medis yang patuh terhadap standar operasioanal prosedur penggunaan masker. Hasil penelitian Ganezak dan Szych (2007) mendeskripsikan hanya $5 \%$ perawat yang peduli dan taat dalam mengunakan sarung tangan, masker, baju pelindung dan kaca 
mata pelindung secara rutin. Data tersebut menunjukkan masih rendahnya tingkat kepatuhan dalam penggunaan APD.

\section{METODE}

Kajian ini menggunakan metode kualitatif, metode ini bersifat memberikan penjelasan dengan membuat analisis. Proses pengkajian ini lebih menggunakan landasan teori dengan mengumpulkan data, bereksplorasi bebas yang telah disimpulkan dari berbagai sumber-sumber, yaitu buku, majalah, koran, jurnal print maupun jurnal online bertema perencanaan keperawatan. Saya membaca dari berbagai referensi berupa buku, jurnal print maupun jurnal online. Melalui metode ini saya memahami dan mengidentikasi upaya pencegahan penyakit apabila perawat patuh dalam menggunakan alat pelindung diri (APD). Kemudian mengetahui apa hal yang akan terjadi apabila tidak patuh dalam menggunakan alat pelindung diri (APD).

\section{HASIL}

Berdasarkan hasil, bahwa perawat yang professional akan patuh dalam menggunakan alat pelindung diri (APD) sebagai upaya dalam pencegahan penyakit akibat kerja. Tetapi, beberapa referensi yang saya baca, terdapat beberapa perawat yang masih lalai dalam melakukan pencegahan penyakit akibat kerja di rumah sakit.
Definisi PAK berdasarkan pandangan informan merupakan penyakit yang berkaitan dengan segi pekerjaan, berkembang, punya efek ke belakang hari, ada paparan tidak langsung yang dapat menyebabkan kecelakaan kerja, dan bisa disebabkan oleh kesalahan diri sendiri atau ceroboh. Penyakit-penyakit yang dikaitkan dengan PAK oleh para informan diantaranya adalah penyakit akibat kebisingan, tidak pakai masker, getaran dan lingkungan, malaria, pernafasan, dan kecelakaan kerja.

Sementara faktor-faktor yang paling sering menyebabkan PAK adalah faktor manusianya atau kurang sadar atau lengah atau ceroboh, atau kelalaian. Faktor lainnya adalah tidak dipatuhinya peraturan safety serta karena alam dan peralatan yang dipakai.

Peran serta para pekerja dalam mencegah PAK merupakan komponen sikap. Para informan sudah mempunyai pengetahuan langkah-langkah mencegah PAK, walaupun masih saja ada yang tidak patuh terhadap prosedur pencegahan PAK di lokasi kerja. Menurut pengetahuan para informan langkah terbanyak yang harus dilakukan adalah mengikuti prosedur safety, diikuti jangan ada kelalaian, ada niat dari diri sendiri, dan adanya pola hidup sehat. 
Ditemukan beberapa faktor resiko yang dapat menyebabkan terjadinya PAK adalah sebagai berikut:

1. Golongan fisik

2. Golongan kimia

3. Golongan infeksi

4. Golongan fisiologis

5. Golongan mental

\section{PEMBAHASAN}

Perawat merupakan petugas kesehatan terbanyak dengan komposisi hampir $60 \%$ dari seluruh petugas kesehatan di rumah sakit dan salah satu profesi yang sering terkena penyakit akibat kerja karena perawat tenaga kesehatan yang 24 jam berada di samping dan bersentuhan dengan pasien (Sudarmo, 2016, p.11). Kontaminasi penyakit dapat berisiko terjadi pada seorang perawat maupun dokter apabila selama melakukan interaksi dengan pasien tidak memperhatikan tindakan pencegahan (universal precaution) dengan cara menggunakan alat pelindung diri (APD) seperti sarung tangan, masker, kaca mata (Riyanto, 2011, p. 81).

Perawat merupakan sumber daya manusia di rumah sakit yang memberikan pelayanan kepada pasien.Universal precaution merupakan pencegahan penularan penyakit dari tenaga kesehatan dan sebaliknya. Kepatuhan dalam penggunaan APD di rumah sakit dipengaruhi oleh komunikasi, keterbatasan alat, pengawasan, dan sikap dari perawat itu sendiri.Kontaminasi penyakit yang terjadi di lingkungan rumah sakit dapat dicegah dengan meningkatkan keamanan dan kedisiplinan perawat dalam menggunakan alat pelindung diri dan itu berlaku bagi semua perawat yang ada di seluruh unit pelayanan (Riyanto, 2011).

Menurut Riyadi (2007), kepatuhan (compliance) merupakan salah satu bentuk perilaku yang dapat dipengaruhi oleh faktor internal maupun eksternal. Penggunaan Alat Pelindung Diri (APD) termasuk faktor lingkungan karena APD merupakan salah satu alat untuk melidungi diri para pekerja guna mengurangi resiko kecelakaan kerja. Jadi, kepatuhan dalam penggunaan alat pelindung diri merupakan perilaku keselamatan spesifik terhadap objek lingkungan kerja. Kepatuhan penggunaan alat pelindung diri memiliki peran yang penting dalam menciptakan keselamatan di tempat kerja. Berbagai contoh perilaku (tindakan) kurang aman yang sering ditemukan di tempat kerja pada dasarnya adalah perilaku tidak patuh terhadap prosedur kerja/operasi, seperti menjalankan mesin atau peralatan tanpa wewenang, mengabaikan peringatan dan keamanan, kesalahan kecepatan pada saat mengoprasikan mesin/ peralatan, tidak menggunakan alat pelindung diri dan 
memperbaiki peralatan yang sedang bergerak atau dalam keadaan hidup atau dengan kata lain tidak mengikuti prosedur kerja yang benar.

Menurut Geller (2001) kepatuhan pelaksanaan standar operasional prosedur penggunaan APD masih rendah disebabkan karena budaya keselamatan yang belum cipta dalam lingkungan kerja. Budaya keselamatan dipengaruhi oleh faktor perilaku,faktor lingkungan dan faktor orang. Keberhasilan upaya pencegahan infeksi yang dilakukan oleh perawat bedah salah satunya penggunaan APD yang wajib dipakai selama berada di kamar operasi, yang tujuannya tidak hanya untuk perlindungan petugas itu sendiri dalam melakukan tindakan yang aman tetapi juga untuk keselamatan pasien. Keberhasilan ini sangat dipengaruhi oleh ketaatan individu pada aturan yang berlaku atau kepatuhan. Upaya pencegahan infeksi yang dilakukan oleh perawat bedah salah satunya dengan penggunaan APD yang wajib dipakai ketika mereka bekerja di kamar operasi.

Kepatuhan dalam penggunaan APD di rumah sakit dipengaruhi oleh beberapa faktor antara lain, komunikasi, keterbatasan alat, pengawasan, dan sikap dari perawat itu sendiri. Kontaminasi penyakit yang terjadi di lingkungan rumah sakit dapat dicegah dengan meningkatkan keamanan dan kedisiplinan perawat dalam menggunakan alat pelindung diri dan itu berlaku bagi semua perawat yang ada di seluruh unit pelayanan. Tenaga perawat yang dihadapkan pada tugas dan tanggung jawab untuk bekerja dalam lingkungan yang membahayakan bagi kesehatan dirinya sendiri dan bahaya tersebut berupa kemungkinan terpaparnya berbagai kuman penyakit yang ditularkan melalui darah, cairan tubuh pasien, dan lain sebagainya (Riyanto, 2016, p. 81).

Penggunaan APD di RS di Indonesia ternyata lebih dari $40 \%$, dan kenyataan di lapangan para perawat ratarata hanya menggunakan salah satu APD (jas lab, sarung tangan, atau masker saja) saat menangani pasien. Adapun alasan perawat tidak menggunakan APD ketika menangani pasien, pada umumnya (52\%) di rumah sakit tidak tersedia APD yang lengkap. Tidak tersedianya APD di rumah sakit kemungkinan di sebabkan karena kurangnya perhatian dari kepala ruang dalam penyediaan APD, atau anggaran rumah sakit yang terbatas sehingga dana untuk pengadaan APD juga menjadi terbatas. Alasan lain perawat karena malas, lupa, tidak terbiasa dan repot. Alasanalasan tersebut sangat terkait dengan kesadaran/perilaku perawat dalam penggunaan APD. Penyebab utamanya kemungkinan karena kurangnya pemahaman perawat terhadap bahaya yang 
akan timbul sebagai akibat dari adanya penyakit yang berbahaya (Sukarjo, 2012, p. 23).

Kebijakan yang mengatur tenaga kerja untuk menggunakan APD harus menyatakan secara jelas bahwa APD sangat dibutuhkan oleh tenaga kerja untuk melindungi dirinya dan wajib dipatuhi. Kebijakan ini juga harus secara tertulis. Menurut Notoatmodjo (2011) kebijakan merupakan faktor pendorong atau memperkuat untuk terjadinya suatu perilaku. Faktor tersebut meliputi undangundang, peraturan, pengawasan dan sebagainya.

Penyakit Akibat Kerja adalah penyakit yang disebabkan oleh pekerjaan dan lingkungan kerja. Faktor risiko PAK antara lain: Golongan fisik, kimiawi, biologis atau psikososial di tempat kerja. Faktor tersebut di dalam lingkungan kerja merupakan penyebab yang pokok dan menentukan terjadinya penyakit akibat kerja. Faktor lain seperti kerentanan individual juga berperan dalam perkembangan penyakit di antara pekerja yang terpajan.

Faktor risiko yang dapat menyebabkan terjadinya PAK adalah sebagai berikut:

1. Golongan fisik

a. Kebisingan dapat mengakibatkan gangguan pada pendengaran sampai dengan Non-induced hearing loss

b. Radiasi (sinar radio aktif) dapat mengakibatkan kelainan darah dan kulit

c. Suhu udara yang tinggi dapat mengakibatkan heat stroke, heat cramps, atau hyperpyrexia. Sedangkan suhu udara yang rendah dapat mengakibatkan frostbite, trenchfoot atau hypothermia.

d. Tekanan udara yang tinggi dapat mengakibatkan caison disease

e. Pencahayaan yang tidak cukup dapat mengakibatkan kelahan mata. Pencahayaan yang tinggi dapat mengakibatkan timbulnya kecelakaan.

2. Golongan kimia

a. Debu dapat mengakibatkan pneumokoniosis

b. Uap dapat mengakibatkan metal fume fever, dermatitis dan keracunan

c. Gas dapat mengakibatkan keracunan $\mathrm{CO}$ dan $\mathrm{H}_{2} \mathrm{~S}$

d. Larutan dapat mengakibatkan dermatitis

e. Insektisi dapat mengakibatkan keracunan

3. Golongan infeksi

a. Anthrax 

b. Brucell
c. HIV/AIDS

4. Golongan fisiologis

Dapat disebabkan oleh kesalahan kontruksi, mesin, sikap badan yang kurang baik, salah cara melakukan suatu pekerjaan yang dapat mengakibatkan kelelahan fisik bahkan lambat laun dapat menyebabkan perubahan fisik pada tubuh pekerja.

5. Golongan mental

Dapat disebabkan oleh hubungan kerja yang tidak baik atau keadaan pekerjaan yang monoton yang menyebabkan kebosanan.

\section{PENUTUP}

Perawat merupakan tenaga kesehatan yang paling sering ditemukan dan paling lama melakukan kontak dengan pasien, sehingga sangat berisiko dengan pekerjaannya, namun banyak perawat tidak menyadari terhadap risiko yang mengancam dirinya yaitu, melupakan keselamatan dan kesehatan kerja (K3).

Kepatuhan terhadap APD itu sendiri merupakan hal wajib yang harus dilakukan oleh perawat, yang berguna dalam mencegah terjadinya kecelakaan kerja maupun mencegah tertular penyakit dari satu pasien ke lainnya.

Oleh karena itu, harus lebih diperhatikan lagi bagi para pembuat kebijakan, keselamatan masyarakat, dan tak terlepas dari keselamatan tenaga medis itu sendiri.

Alat pelindung diri terbukti mampu membantu perawat mempermudah pelayanan kesehatan oleh karena itu pengetahuan tentang alat pelindung diri harus dikuasi penuh oleh perawat sehingga tingkat kepuasan pasien semakin baik. Diperlukannya peningkatan dalam pengawasan terhadap perawat saat melakukan tindakan keperawatan. 


\section{DAFTAR PUSTAKA}

Azizah, Nur. Setiawan. Silaban, Gerry. (2019). HUBUNGAN ANTARA PENGAWASAN, PROSEDUR KERJA DAN KONDISI FISIK DENGAN TERJADINYA KECELAKAAN KERJA PADA PERAWAT DI RUANG RAWAT INAP RUMAH SAKITPERMATA BUNDA MEDAN TAHUN 2017. Jurnal JUMANTIK Vol. 3 No.2, 125-134

Hasugian, Armedy Ronny. (2017). Perilaku Pencegahan Penyakit Akibat Kerja Tenaga Kerja Indonesia di Kansashi, Zambia: Analisis Kualitatif. Media Litbangkes, Vol. 27 No. 2, 111-124 Maria P. I, Silvia. Wiyono, Joko. Candrawati, Erlisa. (2015). KEJADIAN KECELAKAAN KERJA PERAWAT BERDASARKAN TINDAKAN TIDAK AMAN. Jurnal Care Vol. 3, No. $2,9-17$

Muchlis, Sayed. Yusuf, Muhammad. KESADARAN PERAWAT DALAM PENGGUNAAN ALAT PELINDUNG DIRI (APD). JURNAL ILMIAH MAHASISWA FAKULTAS KEPERAWATAN. ISSN: 2716-3555. 1-8

Ramdan, I., M., Rahman, A. (2017). Analisis Risiko Kesehatan dan Keselamatan Kerja (K3) pada Perawat. Jurnal Keperawatan padjadjaran Vol 5, No 3.

Salawati, Liza. (2015). PENYAKIT AKIBAT KERJA DAN PENCEGAHAN. JURNAL KEDOKTERAN SYIAH KUALA Volume 15 Nomor 2. 91-95

Setyawan, Haris. Sjariah, Ipop. (2015). IMPLEMENTASI 5R UNTUK MENCEGAH PENYAKIT AKIBAT KERJA PADA GIGI, MULUT DAN SALURAN PERNAFASAN DI INDUSTRI INFORMAL SRAGEN. Jurnal Kesehatan Gigi Vol. 2 No.2, 84-91

Simamora, R. H. (2020). Pelatihan Komunikasi Efektif untuk Meningkatkan Efikasi diri Perawat dalam Pelaksanaan Identifikasi Pasien. JURNAL ILMIAH KESEHATAN MASYARAKAT: Media Komunikasi Komunitas Kesehatan Masyarakat, 12(1), 49-54.

Soemarko, Dewi Sumaryani. (2012). PENYAKIT AKIBAT KERJA "Identifikasi dan rehabilitasi kerja”. K3 Expo Seminar SMESCO, 1-6

Sudarmo. Helmi, Zairin Noor. Marlinae, Lenie. (2016). FAKTOR YANG MEMPENGARUHI PERILAKU TERHADAP KEPATUHAN PENGGUNAAN ALAT PELINDUNG DIRI (APD) UNTUK PENCEGAHAN PENYAKIT AKIBAT KERJA. Jurnal Berkala Kesehatan, Vol. 1, No. 2, 88-95 
Tukatman., Sulistiawati., Purwaningsih., Nursalam. (2015). ANALISIS KESELAMATAN DAN KESEHATAN KERJA PERAWAT DALAM PENANGANAN PASIEN DI RUMAH SAKIT BENYAMIN GULUH KABUPATEN KOLAKA. Jurnal Ners Vol. 10 No. 2, 343-347 